\title{
A RECONSIDERATION OF \\ THE OXYOPES APOLLO SPECIES GROUP WITH THE DESCRIPTIONS OF \\ TWO NEW SPECIES (ARANEAE: OXYOPIDAE)*
}

\author{
By Allen R. Brady \\ Hope College, Holland, Michigan 49423
}

The lynx spiders, Oxyopidae, are represented by a small but diverse group of species in North America, north of Mexico. Three genera including I7 species were recorded and described from this region (Brady, 1964). Eight new species were described in the genus Oxyopes. Of these eight new species, six were placed in the Oxyopes apollo species group consisting of Oxyopes apollo, floridanus, tridens, pardus, lynx and felinus. These six species were grouped on the basis of similarities in genitalia, body structure, color pattern, and relative length of legs. With the accumulation of additional material a re-evaluation of the apollo group is necessary. Collections from North Carolina, Florida and Texas indicate that $O$. apollo and $O$. floridanus are conspecific. Among specimens from Arizona were included one new species and an undescribed female, both related to members of the apollo group. Additional Florida collections have revealed for the first time numerous specimens of a species described as Oxyopes lanceolatus (Walckenaer) by Chamberlin and Ivie (1944), but here considered a new species and a member of the apollo group.

In light of this new information a dendrogram representing the relationships of the species in the apollo group is shown in Text Figure I. This comparison of the morphological features of these species takes into account their distribution as far as it is known.

Consideration of the dendrogram as a phylogeny of the species involved allows speculation and the construction of a generalized picture of the origin and dispersal routes of these North American oxyopids.

The apollo species group can be separated into two subgroups: $\mathrm{A}$, represented by $O$. apollo and $O$. artemis; and $\mathrm{B}$, represented by O. tridens, pardus, lynx, cougar and felinus. Both subgroups $\mathrm{A}$ and $B$ have eastern and western representatives. The similarity of epigynal structure between $O$. apollo and $O$. artemis (compare figs. 47, 48 of Brady, 1964, with Figs. I3-I5 of this paper) indicates a rela-

*Manuscript received by the editor September 9, 1969 


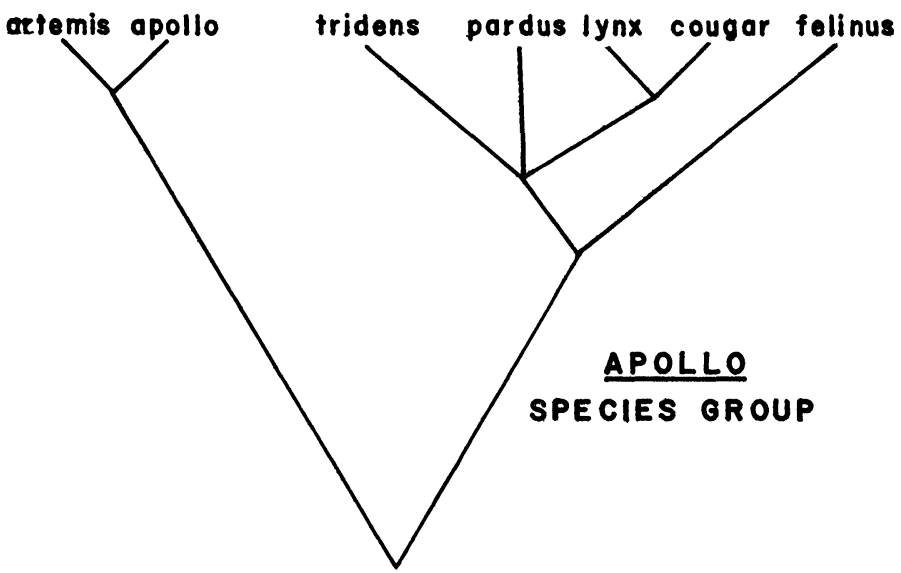

Text Figure 1. Dendrogram illustrating the hypothetical relationships of North American members of the Apollo species group.

tively recent common ancestry. Likewise the similarity between the palpal structure of $O, l y n x$ and $O$. cougar (compare figs. 66, 67 of Brady, 1964 with Figs. 9, Io of this paper) indicate a recent linkage. In fact, the entire apollo species group appears to have originated in Mexico and/or Central America, perhaps after being separated via the Panamian bottle-neck from earlier South American ancestors. Expanding northward these founder populations extended into the southwestern United States on the one hand and along the Gulf Coast into Florida on the other hand.

I suggest that the exploitation of widely dissimilar ecological realms in the southwestern and the southeastern United States produced entirely different sets of selective pressures. Gene flow between the western and eastern populations would tend to be limited, and it is doubtful whether the eastern and western populations would remain conspecific for long. Exceptional cases would involve ancestral Neotropical populations that remained as a strong connecting link between east and west, or species populations that might be genetically flexible enough to meet the widely differing environments of the southern United States from east to west.

Thus, in general, the effect of expansion into North America would be to produce biological divergence and subsequent speciation in many cases. This idea would be supported if one were to find examples of closely related allopatric species in the southeast and the southwest. Oxyopes apollo is predominately southeastern in dis- 
tribution and $O$. artemis is apparently restricted to the southwest. Oxyopes cougar has been found only in the southeast and $O$. lynx is from Marathon, Texas, far to the west of $O$. cougar. Better evidence for an east-west divergence influencing speciation is seen in the distribution patterns of $O$. acleistus - O. occidens (Brady, I964) and the lycosids Sosippus floridanus - S. californicus (Brady, I962). Only the effect of a geographic divergence has been emphasized until now, but time must be given equal consideration. Successive waves of colonization would play an important role in the process of speciation. Populations moving into North America from a southern route at different times would further complicate the evolutionary picture. Intensive and widespread collecting in Mexico and Central America will undoubetedly give clues to the temporal sequence as well as elucidate the geographic patterns of speciation in the apollo species group.

For collections which made this study possible I especially thank Dr. Donald C. Lowrie and Dr. W. D. Stockton of California State College at Long Beach, Dr. Howard V. Weems, Curator for the Florida State Collection of Arthropods, and Dr. Joseph A. Beatty of Southern Illinois University. These collections included the new species described here and the hypothesis concerning the effect of geographic movements on speciation of oxyopids was arrived at through a study of these collections.

I also wish to thank Dr. H. W. Levi and Mrs. Lorna Levi, who were kind enough to read the original manuscript. National Science Foundation grant number GB-I3925 helped to defray expenses involved with this investigation.

\section{Oxyopes apollo Brady}

Oxyopes helius: Bryant, 1936, Psyche, 36(4): 92, fig. 7, $\hat{\delta}$, not $O$. helius Chamberlin.

Oxyopes apollo Brady, 1964, Bull. Mus. Comp. Zool., 131(13): 467, figs. 41, 42, 47-50, 72-75, ㅇ, $\hat{\delta}$. Male holotype from Encino, Brooks Co., Texas in the American Museum of Natural History.

Oxyopes floridanus Brady, 1964, Bull. Mus. Comp. Zool., 131(13): 469, figs. 43, 44, 51, 76-79, 우, $\hat{o}$. Male holotype from Volusia Co., Florida in the Museum of Comparative Zoology. NEW SYNONYMY

Discussion. On the basis of a smaller retrolateral patellar apophysis and a denser clothing of appressed white hair over the body and legs of Florida specimens, I ( I964) recognized them as a distinct species from Oxyopes apollo found from Tennessee to northern Mexico. Ernst Mayr (personal communication) pointed out at the time that the slight morphological differences might better be interpreted as a response to geographic conditions. 

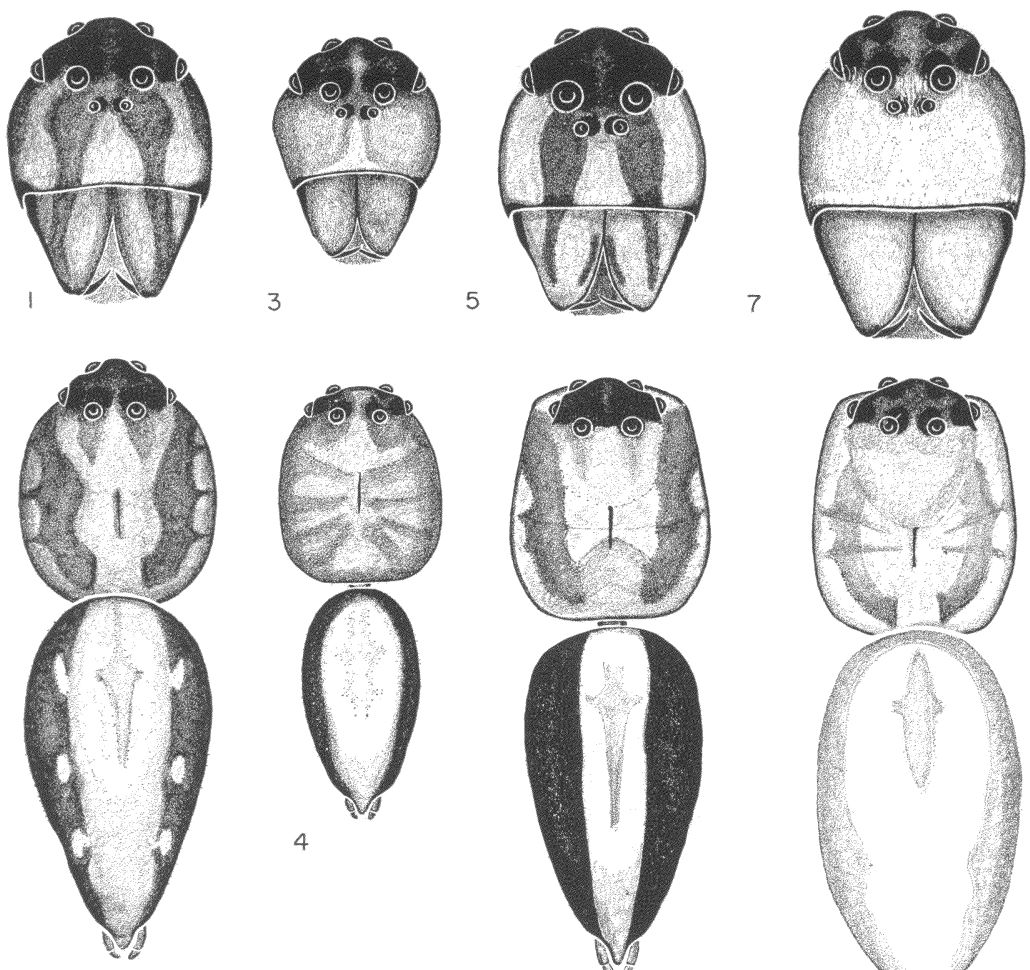

2
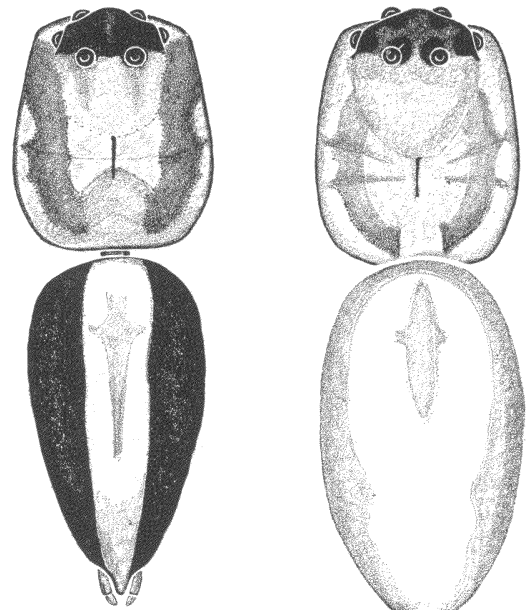

6

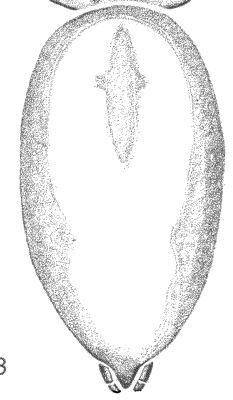

Figs. 1-2. Oxyopes cougar, sp. n., female from Saufley Heights near Pensacola, Escambia Co., Florida, 8 Sept. 1945. 1. Face view. 2. Dorsal view.

Figs. 3-4. Oxyopes cougar, sp. n., male holotype from Saufley Heights near Pensacola, Escambia Co., Florida, 4 Aug. 1945. 3. Face view. 4. Dorsal view.

Figs. 5-6. Oxyopes sp., female from $12 \mathrm{mi}$. W of Portal, Cochise Co., Arizona, 13 July 1968. 5. Face view. 6. Dorsal view.

Figs. 7-8. Oxyopes artemis, sp. n., female holotype from $15 \mathrm{mi}$. S of Florence, Pinal Co., Arizona. 12 July 1968. 7. Face view. 8. Dorsal view. 
The distribution patterns in two other groups of spiders, Sosippus, a lycosid genus, and the Oxyopes acleistus species group (see Brady, I 962 and 1964) lent credence to the idea of a distinct Florida species related to $O$. apollo. In both Sosippus and Oxyopes there are distinct species whose range does not extend beyond peninsular Florida. Also the specimens of Oxyopes apollo examined prior to 1964 did not exhibit much variation from Tennessee to northern Mexico.

After examination of a large series of specimens from Texas and several specimuns from North Carolina, it became clear that Oxyopes floridanus should be considered a synonym of $O$. apollo. The size of patellar apophyses in males from Durham, North Carolina and Sinton, Texas range from that of typical Florida specimens to that of the earlier examined specimens from Texas described as $O$. apollo.

A number of specimens from Oaxaca, Mexico, smaller and much lighter in color than more northerly specimens of $O$. apollo, have epigyna or palpi identical to northern populations. These are now also considered conspecific members of this widespread species. New records for specimens of Oxyopes apollo examined are given below.

Natural History. In 1964 I reported Oxyopes apollo collected from pitfall traps in Arkansas. Specimens collected near Durham, North Carolina were also taken in pitfall traps. Although sweeping vegetation in both these regions had yielded other species of Oxyopes, $O$. apollo was not captured by this method.

Collections over a period of two years near Sinton, Texas, disclosed a very high density of $O$. apollo. Approximately 150 specimens were taken during eight collecting dates from April through September. A single day in September yielded over 50 specimens. Presumably these were taken by sweep-net. Lowrie (1969) reports $O$. apollo taken in sweeping herbaceous vegetation near Pensacola, Florida. It appears that $O$. apollo occupies dissimilar habitats or is much less abundant in different parts of its range than in others. At least in the southern sections of its range it occurs abundantly on vegetation and is taken by sweeping.

New Records. North Carolina: Durham Co.: near Chapel Hill, 20 Sept. I963, o; 5 mi. E of Chapel Hill, I July 1964, ơ ơ 7 ; 2 mi. $\mathrm{S}$ of Durham, I4 July I964, ot (J. W. Berry). FloRIDA: Escambia Co.: Pensacola, 4 June 1945, $\sigma^{\top}$ (D. Lowrie). texas: San Patricio Co.: 8 mi. NE of Sinton, 28 July I959, $0^{7} \sigma^{7}$ o, 4 Sept. 1959, $510^{7} \sigma^{7}:$ 9웅, 18 Sept. 1959, $520^{x} 0^{x}: 690$, 30 Sept. 1959, $180^{x} 0^{x}$, 15 Oct.

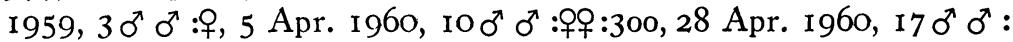
ㅇ, I2 May 1960, $50^{\lambda} 0^{\lambda}+$, 26 May 1960, $0^{\pi}+$, I 2 June 1960, 우:400, 
July 1960, $180^{x} \sigma^{x}: 4$ 우 :1 180o, ig Aug. 1960, $220^{x} \sigma^{x}$, Sept. 1960, $350^{\pi} 0^{7}: 17$ 웅 (H. E. Laughlin). Mexico, OAXACA: Jalapa, 28 Aug. 1947, $\sigma^{\pi}$; Tuchitan, 30 Aug. 1947, $\sigma^{x} \sigma^{x}: 9$ 우:o (H. Wagner).

\section{Oxyopes artemis sp. n.}

\section{Figures 7,8, I3-1 5}

Holotype. Female from I 5 mi. S of Florence, Pinal Co., Arizona, 12 July 1968 (L. D. Mikelson) in the Museum of Comparative Zoology. The specific name is a noun in apposition after the Greek goddess Artemis.

Discussion. One of the distinguishing characteristics of members of the apollo species group is the robust fourth legs. In other species of Oxyopes leg I is the longest and most powerfully developed. In those species with leg I longest the patella-tibia of a given leg is longer than any of the other leg segments and is a good indicator of relative leg length. In members of the apollo group, even though the patella-tibia of leg I may exceed the patella-tibia of leg IV in length, femur IV and metatarsus IV equal or exceed patella-tibia IV in length and leg IV is much the longest. For an adequate comparison of members of this group, therefore, the measurements of segments of leg I and leg IV are given below. The robust development of leg IV in species of the apollo group is undoubtedly related to their jumping ability and may be associated with their ecology, for example, their occurrence in rather barren areas in some cases.

Measurements. Length of three females $5.2-5.6 \mathrm{~mm}$, carapace width $\mathrm{r} .8 \mathrm{~mm}$, carapace length $2.3-2.4 \mathrm{~mm}$.

Width of eye rows: AME .25-.36 mm, ALE .54-.58 mm, PLE I.03-1.08 mm, PME .54-.56 mm.

Segments of legs I and IV: femur 2.0-2.I mm, 2.7-2.8 mm, patella-tibia 2.3-2.4 mm, 2.5-2.6 mm, metatarsus $2.1 \mathrm{~mm}, 3.1-3.2 \mathrm{~mm}$, tarsus $.8-.9 \mathrm{~mm}, .8-.9 \mathrm{~mm}$, total length 7.2-7.5 mm, 9.2-9.5 mm.

Length of patella-tibiae: II $2.2-2.3 \mathrm{~mm}$, III I.6-I.7 mm.

Color. Female. Pattern illustrated in Figures 7 and 8. Face and chelicerae pale orange-yellow to cream. White spatulate shaped, appressed hair covering much of face and base of chelicerae. These white hairs thickest between ALE to AME, covering most of hexagonal region bounded by eyes in unrubbed specimens. An inverted T-shaped mark running from the AME to the lower edge of the clypeus is also formed by a dense alignment of these white hairs.

Carapace pale orange-yellow to cream with light brown sub- 
marginal stripes beginning in cephalic region and continuing to posterior declivity.

Dorsum of abdomen wrinkled in these specimens, pale orangeyellow with abundance of white appressed hairs giving it an ivory appearance. Indistinct brownish markings in cardiac region and along sides. Venter cream colored to ivory with abundant close-packed, flattened white hair.

Legs cream to ivory without darker markings.

Labium and endites ivory. Sternum ivory with four pairs of dark, brownish spots laterally and a single one posteriorly.

Diagnosis. Oxyopes artemis is most closely related to $O$. apollo among the members of the apollo species group (see Text Figure I). It is readily distinguished from $O$. apollo by the structure of the epigynum (compare Figs. I3-I5 of this paper with figs. 47,48 of Brady, I964). In $O$. artemis the epigynum is larger and relatively broader than in $O$. apollo. The much lighter color of $O$. artemis also distinguishes it from $O$. apollo throughout most of the latter's range. Specimens of $O$. apollo from Oaxaca, Mexico, however, resemble $O$. artemis in color.

Record. Arizona. Pinal Co.: 15 mi. S of Florence, I, $440 \mathrm{ft}$., 3 우 (L. D. Mikelson).

\section{Oxyopes cougar sp. $\mathrm{n}$.}

Figures I-4, 9-I2,

Holotype. Male from $8 \mathrm{mi}$. NW of Pensacola, Escambia Co., Florida, I 8 Aug. I945 (D. Lowrie) in the Museum of Comparative Zoology. The specific name is a noun in apposition after the Cougar.

Oxyopes lanceolatus: Chamberlin and Ivie, r944, Bull. Univ. Utah, biol. ser., 8(5) :I32, figs. I80, I8I, not Sphasus lanceolatus Walckenaer.

Discussion. Chamberlin and Ivie (1944) redescribed and figured what they considered to be the neotype of Sphasus lanceolatus, a name based upon Abbot's drawing number 42 in the "Spiders of the Georgia Region" (see Brady, I964, 439-442). Figure 42 of Abbot's is not the species described as Oxyopes lanceolatus by Chamberlin and Ivie. Compare Text Figure 2 with Figure 2, page 429. The color pattern in Abbot's Figure 42 is close to that of $O$. scalaris Hentz, but also resembles $O$. aglossus, and $O$. acleistus. Also, if Abbot's drawings are to be considered accurate, the robust fourth pair of legs, characteristic of Oxyopes cougar, are not evident. Instead the first pair of legs are longer and more strongly developed as are those 


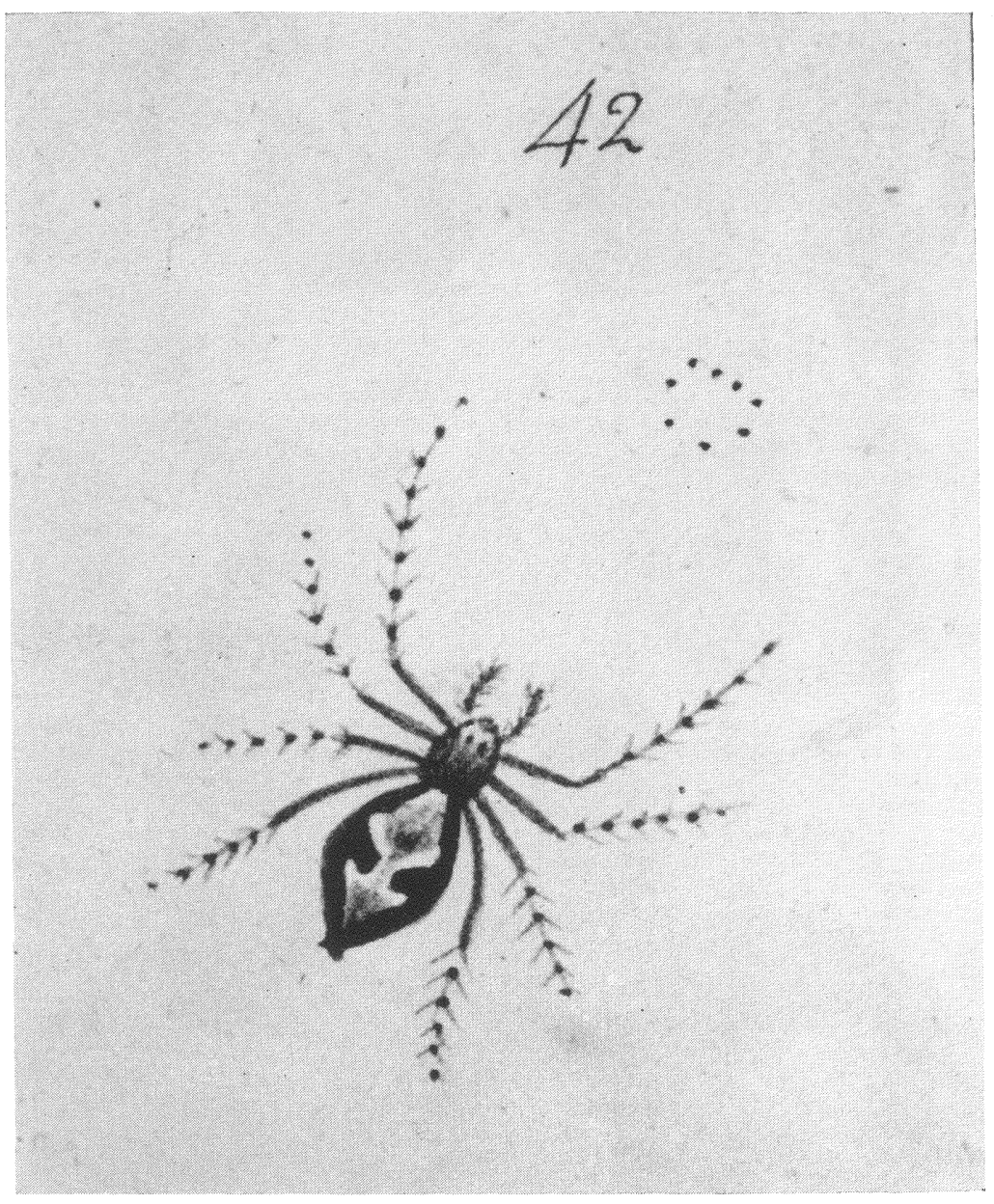

Text Figure 2. Enlarged photograph of Abbot's Figure 42 in the "Spiders of the Georgia Region". Note length of first legs compared to length of fourth legs. 

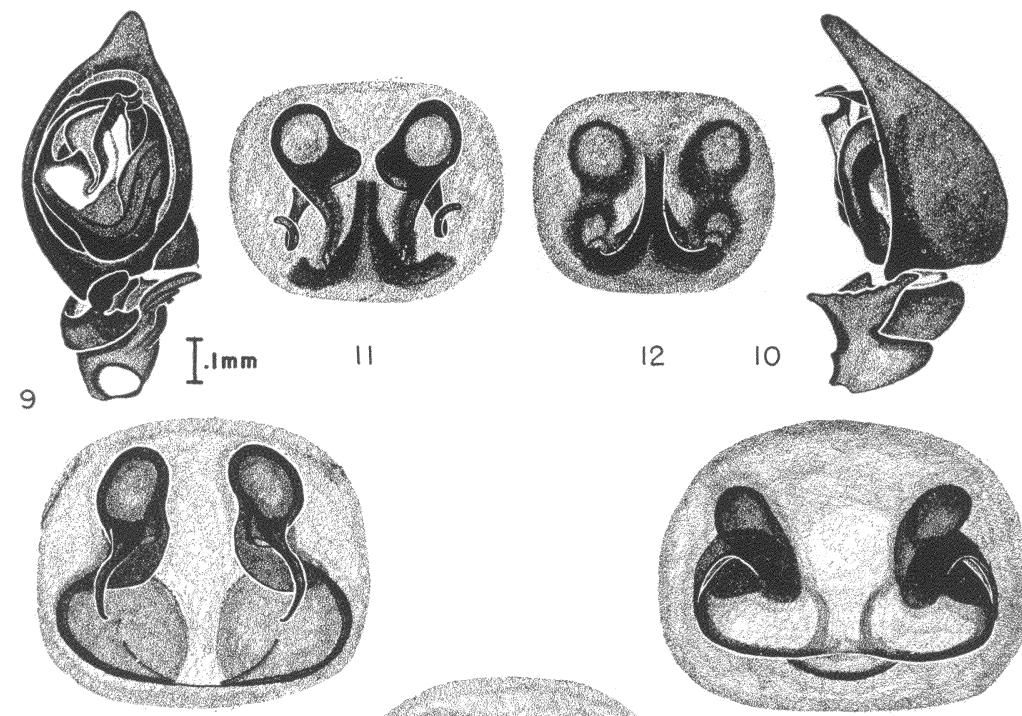

13

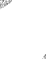
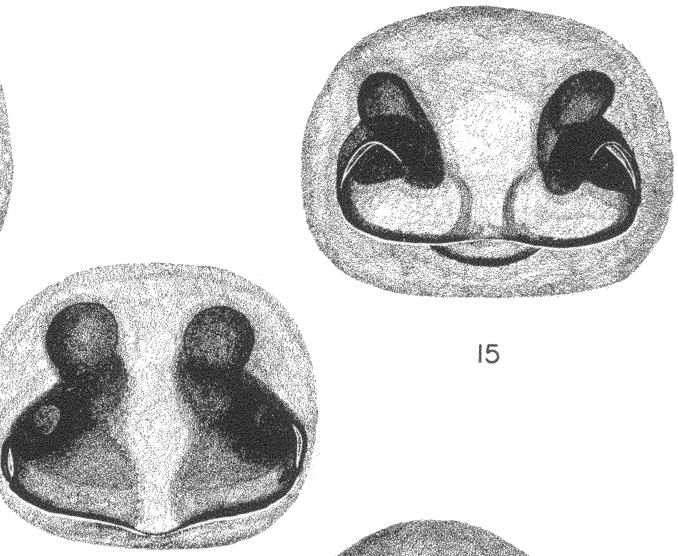

15

14

$$
\stackrel{.1 \mathrm{~mm}}{\longrightarrow}
$$

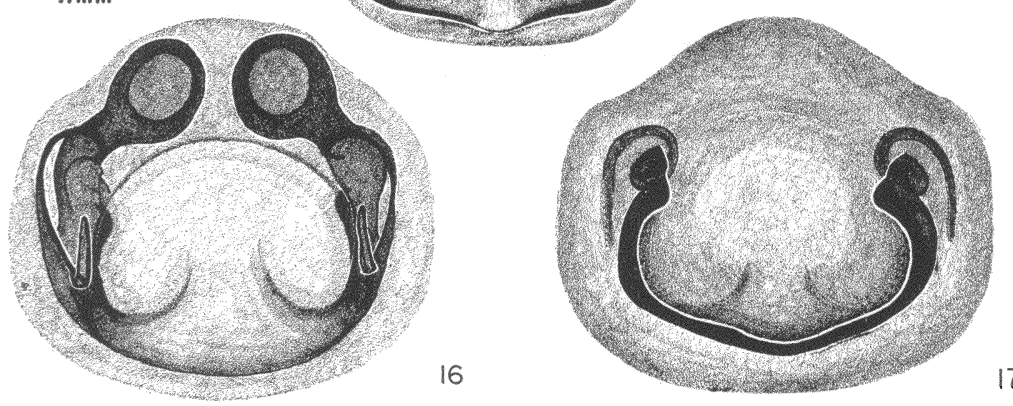

Figs. 9-10. Oxyopes cougar sp. n., male holotype from Saufley Heights near Pensacola, Escambia Co., Florida, 4 Aug. 1945. 9. Left palpus, ventral view. 10. Left palpus, retrolateral view.

Figs. 11-12. Oxyopes cougar sp. n., female from Saufley Heights near Pensacola, Escambia Co., Florida, 8 Sept. 1945. 11. Internal genitalia, dorsal view. 12. Epigynum.

Figs. 13-15. Oxyopes artemis sp. n., females from $15 \mathrm{mi}$. S. of Florence, 
of $O$. scalaris, $O$. aglossus and $O$. acleistus. Oxyopes lanceolatus is best considered a nomen dubium.

Measurements. Length of nine males $3.4-4.0 \mathrm{~mm}$, mean $3.7 \mathrm{I} \mathrm{mm}$, carapace width $\mathrm{I} .3-\mathrm{I} .4 \mathrm{~mm}$, mean $\mathrm{I} .36 \mathrm{~mm}$, carapace length I.6-2.0 $\mathrm{mm}$, mean $1.78 \mathrm{~mm}$.

Width of eye rows: AME .25-.30 mm, mean .27I mm, ALE .46$.54 \mathrm{~mm}$, mean .493 mm, PLE .83-.99 mm, mean .899 mm, PME .46$.54 \mathrm{~mm}$, mean .489 $\mathrm{mm}$.

Segments of leg I and IV: femur I I.5-I.8 mm, mean $1.67 \mathrm{~mm}$, IV r.6-2.0 mm, mean r.86 mm, patella-tibia I r.9-2.2 $\mathrm{mm}$, mean I.98 mm, IV I.7-2.1 mm, mean $1.87 \mathrm{~mm}$, metatarsus I I.8-2.0 mm, mean $1.93 \mathrm{~mm}$, IV I.9-2.3 mm, mean $2.17 \mathrm{~mm}$, tarsus I .85-.9 mm, mean $.88 \mathrm{~mm}$, IV .7-.9 mm, mean .79 mm, total length I $6.0-6.9 \mathrm{~mm}$, mean $6.47 \mathrm{~mm}$, IV $6.0-7.3 \mathrm{~mm}$, mean $6.68 \mathrm{~mm}$.

Length of patella-tibiae: II 1.6-2.0 mm, mean I.79 mm, III I.2I.5 mm, mean $1.32 \mathrm{~mm}$.

Length of Io females: $3.9-5.9 \mathrm{~mm}$, mean $5.10 \mathrm{~mm}$, carapace width I.4-I.7 mm, mean $1.57 \mathrm{~mm}$, carapace length $1.8-2.2 \mathrm{~mm}$, mean $2.07 \mathrm{~mm}$.

Width of eye rows: AME .28-.33 mm, mean .303 mm, ALE .5O$.60 \mathrm{~mm}$, mean $.555 \mathrm{~mm}$, PLE .93-1.09 mm, mean $1.003 \mathrm{~mm}$, PME $.50-.60 \mathrm{~mm}$, mean $.555 \mathrm{~mm}$.

Segments of leg I and IV: femur I I.7-2.0 mm, mean I.87 mm, IV I.9-2.5 mm, mean $2.20 \mathrm{~mm}$, patella-tibia I $1.9-2.3 \mathrm{~mm}$, mean 2.I $2 \mathrm{~mm}$, IV I.8-2.4 mm, mean $2.12 \mathrm{~mm}$, metatarsus I I.6-2.I mm, mean $1.87 \mathrm{~mm}$, IV 2.0-2.7 mm, mean $2.42 \mathrm{~mm}$, tarsus I .7-.9 mm, mean $.75 \mathrm{~mm}$, IV .7-.9 mm, mean $.80 \mathrm{~mm}$, total length I $5.9-7.2 \mathrm{~mm}$, mean $6.68 \mathrm{~mm}$, IV $6.4-8.3 \mathrm{~mm}$, mean $7.54 \mathrm{~mm}$.

Patella-tibiae: II 1.7-2.I mm, mean $1.96 \mathrm{~mm}$, III I.3-1.6 mm, mean $1.45 \mathrm{~mm}$.

Color. Male. Pattern illustrated in Figures 3 and 4. Face and chelicerae yellow-orange to orange-brown with faint dusky stripes from ALE to distal ends of chelicerae. Lower edge of clypeus and distal ends of chelicerae often lighter, yellowish. Iridescent scale-like hairs between ALE. Cymbia of palpi black.

Carapace yellow-orange to orange-brown, dusky along vertical sides.

Pinal Co., Arizona, 12 July 1968. 13. Internal genitalia, dorsal view. 14. Epigynum, openings to seminal receptacles plugged. 15. Epigynum of holotype tilted slightly more anteriorly than Fig. 14, seminal receptacles open.

Figs. 16-17. Oxyopes sp., female from $12 \mathrm{mi}$. W of Portal, Cochise Co., Arizona, 13 July 1968. 16. Internal genitalia, dorsal view. 17. Epigynum. 
Dorsum of abdomen with very broad, white to cream, median stripe bounded laterally by dark brown areas. Venter yellow with two thin dusky longitudinal stripes from epigastric furrow to base of spinnerets, bordered by thin yellow stripes which are in turn flanked by dusky or sometimes brown color forming a very wide median stripe. Venter overlaid with scale-like iridescent hairs.

Legs yellow.

Labium dark brown, distal end lighter, yellowish. Endites yellow. Sternum yellow, periphery brown.

Female. Pattern illustrated in Figures I and 2. Face and chelicerae pale yellow to yellow-orange with brownish strires beginning under ALE, widest at level of AME, and continuing to distal ends of chelicerae. White appressed hair between ALE and alcng sides of face. Lower edge of clypeus yellowish.

Median area of carapace yellow-orange with wide, irregular, brown stripes beginning below PLE and continuing to posterior declivity.

Dorsum of abdomen with broad median white stripe from base to tip, bounded by dark brown or black laterally. Card:ac area slightly darker than enclosing stripe. Venter with two narrow brown stripes from epigastric furrow to spinnerets, bounded by thin yellow to cream stripes which are in turn flanked by brown. Brown color sometimes filling median space between two narrow brown stripes and forming a single broad median stripe.

Legs yellow to yellow-orange with distal ends of femora and more distal leg segments with dusky bands.

Labium dark brown to black with distal end yellowish. Endites yellow-orange, dusky along outer edges. Sternum pale yellow, bordered by dark brown or black.

Diagnosis. Oxyopes cougar is very closely related to $O$. lynx from Marathon, Texas. There is a strong resemblance in the palpal sclerites and the patellar apophyses of these two species (compare Figs. 9, Io of this paper with figs. 66, 67 of Brady, 1964). Oxyopes cougar is considerably smaller than $O$. lynx and the patellar apophysis and palpal structure is distinct from $O$. lynx. When the female of $O$. lynx is known, the relationship of these two species will be more clearly established.

Natural History. Oxyopes cougar was taken in pitfall traps in a Broomsedge field in Durham Co., North Carolina. Sweeping vegetation in this area did not yield any specimens. Lowrie (1969) collected moderate numbers of this species from June through September in herbaceous vegetation of a long-leafed pine (Pinus palustris Mill.) 
woods near Pensacola, Florida. All of these specimens were taken in sweep-net samples.

Distribution. North Carolina to western Florida.

Records. NORTh carolina: Durham Co., Chapel Hill Blvd., $\mathrm{E}$ of Co. line, 20 June I963, o, I6 July I963, ㅇ, I7 Apr. I964, o (J. W. Berry). Georgia: Billy's Island, Okefenokee Swamp, June, I9I2, ơo (C. R. Crosby). FLorida: Escambia Co.: $8 \mathrm{mi}$. WNW of Pensacola, 20 Apr. 1945, $0^{\pi} \sigma^{\top}: 300$, I June 1945, $0^{\pi}$ Poo, 4 June 1945, + , I I June 1945, ơ $q$, 6 July 1945, + , io July 1945,

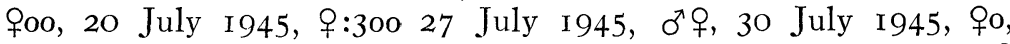

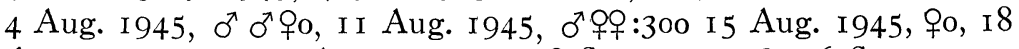
Aug. I945, ơ 0, 25 Aug. 1945, 0 8 , 8 Sept. 1945, + , I6 Sept. I945, ㅇo, 21 Sept. I945, ㅇoo, 19 June 1966, ơ, 17 July 1966, +oo (D. Lowrie).

\section{Oxyopes sp.}

Figures $5,6,16,17$

Discussion. A female Oxyopes from $12 \mathrm{mi}$. W of Portal was included with a number of interesting specimens from Arizona collected by L. D. Mikelson. In preliminary sorting this specimen was identified as Oxyopes tridens Brady. The color pattern is very similar to $O$. tridens and the epigynum resembles that species superficially. A closer examination revealed this spider to be quite different from $O$. tridens, particularly in the structure of the genitalia (compare Figs. I6, I7 of this paper with figs. 53-55 of Brady, 1964).

Three species, $O$. pardus, $O$. lynx and $O$. felinus, have males which resemble this female in coloration. The females of these three species, all of which occur in the southwestern United States, are unknown. Therefore, I think it is very possible that this solitary female belongs to one of the above species. Because $O$. lynx is so close to $O$. cougar, I suspect that the female of $O$. lynx will resemble that species. The new female described here, then, probably belongs in $O$. felinus or $O$. pardus.

Measurements. Length of female $5.4 \mathrm{~mm}$, carapace width $1.7 \mathrm{~mm}$, carapace length $2.3 \mathrm{~mm}$.

Width of eye rows: AME .I9 mm, ALE .60 mm, PLE $1.09 \mathrm{~mm}$, PME .60 mm.

Segments of leg I and IV: femur, $2.0 \mathrm{~mm}, 2.4 \mathrm{~mm}$, patella-tibia $2.4 \mathrm{~mm}, 2.4 \mathrm{~mm}$, metatarsus $2.0 \mathrm{~mm}, 3.0 \mathrm{~mm}$, tarsus $.9 \mathrm{~mm}, .9 \mathrm{~mm}$, total length $7.3 \mathrm{~mm}, 8.7 \mathrm{~mm}$.

Length of patella-tibiae: II $2.3 \mathrm{~mm}$, III $\mathrm{I} .7 \mathrm{~mm}$.

Color. Female. Pattern illustrated in Figures 5 and 6. Face 
and chelicerae pale yellow to cream with two dusky stripes from ALE to subdistal region of chelicerae. Eye region black.

Carapace pale yellow to cream with a pair of broad dusky stripes beginning at level of PME and continuing to thoracic declivity.

Dorsum of abdomen with wide median white stripe from base to tip, bounded by black on each side. Sides cream, mottled with black. Venter with broad, dark brown or black median stripe from epigastric furrow to base of spinnerets, bordered by narrow cream or white stripes.

Legs pale yellow to cream with dusky stripes evident on femora, particularly ventral surfaces. Other leg segments with irregular dark markings.

Labium pale yellow-brown, distal end ivory. Endites pale yellow. Sternum cream to ivory with dusky splotches at periphery and black mark posteriorly between bases of fourth coxae.

Diagnosis. This species is without doubt a member of the apollo group. The color pattern, epigynal structure and the long, robust fourth pair of legs ally it with these oxyopids. Since three of the southwestern species of the apollo group are known only from males, it is likely that this female may be conspecific with one of them. It is described here to differentiate it from $O$. tridens with which it may be confused because of a superficial resemblance. The best guess now is that this specimen represents the female of $O$. pardus or $O$. felinus.

Record. ARIzona: Cochise Co.: $12 \mathrm{mi}$. W of Portal on Recreation Rd., 6,000 ft., ㅇ (L. D. Mikelson).

\section{REFERENCES}

BRADY, A. R.

1962. The spider genus Sosippus in North America, Mexico and Central America (Araneae, Lycosidae). Psyche, 69(3): 129-164.

1964. The lynx spiders of North America, north of Mexico (Araneae: Oxyopidae). Bull. Mus. Comp. Zool., 131(13): 429-518.

Chamberlin, R. V. and W. Ivie

1944. Spiders of the Georgia region of North America. Bull. Univ. Utah, biol. ser., 8(5): 1-267.

LOWRIE, D.

1969. Diurnal-nocturnal, seasonal, grazing and sampling effects on populations of oxyopid spiders (Araneae: Oxyopidae). manuscript. 

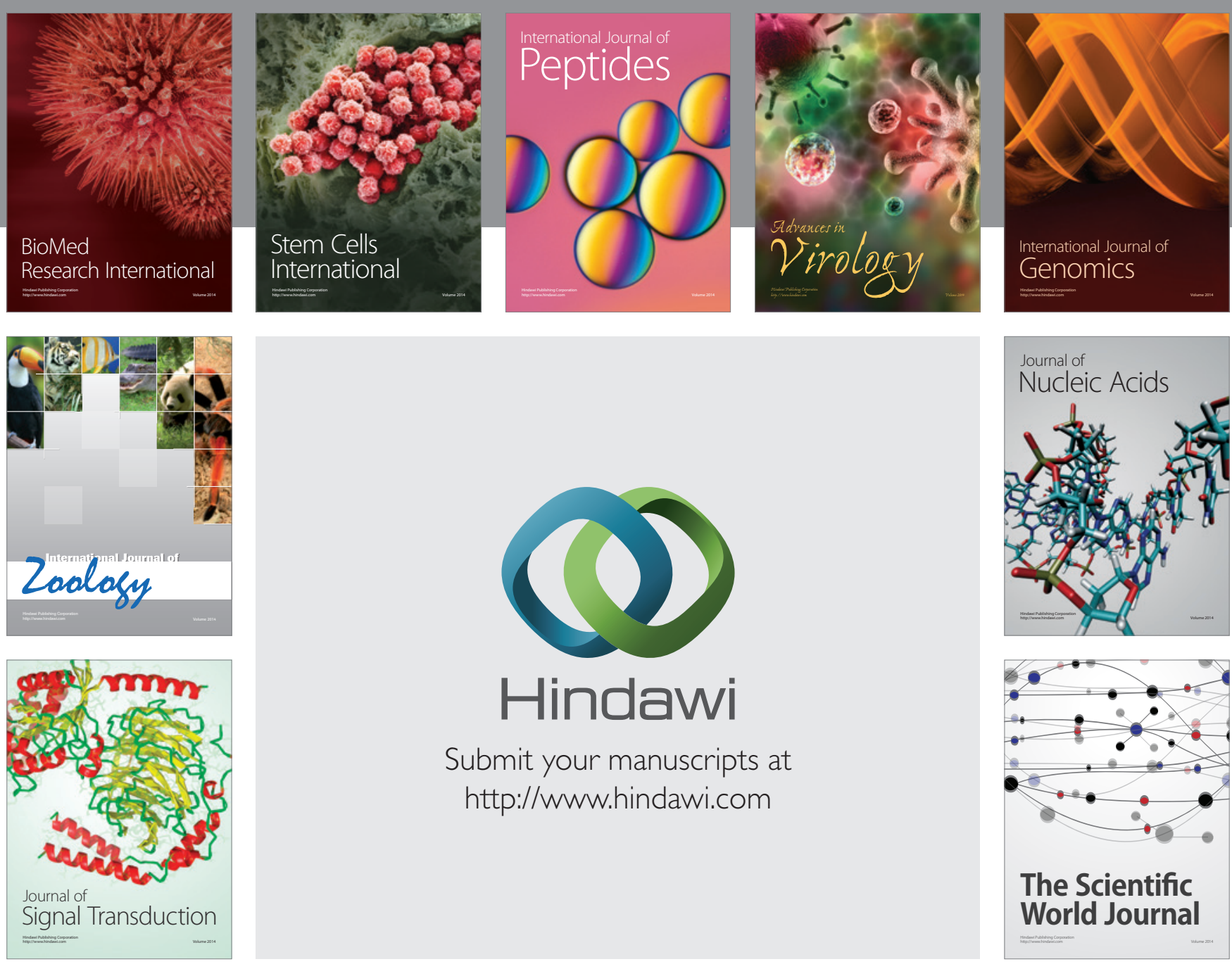

Submit your manuscripts at

http://www.hindawi.com
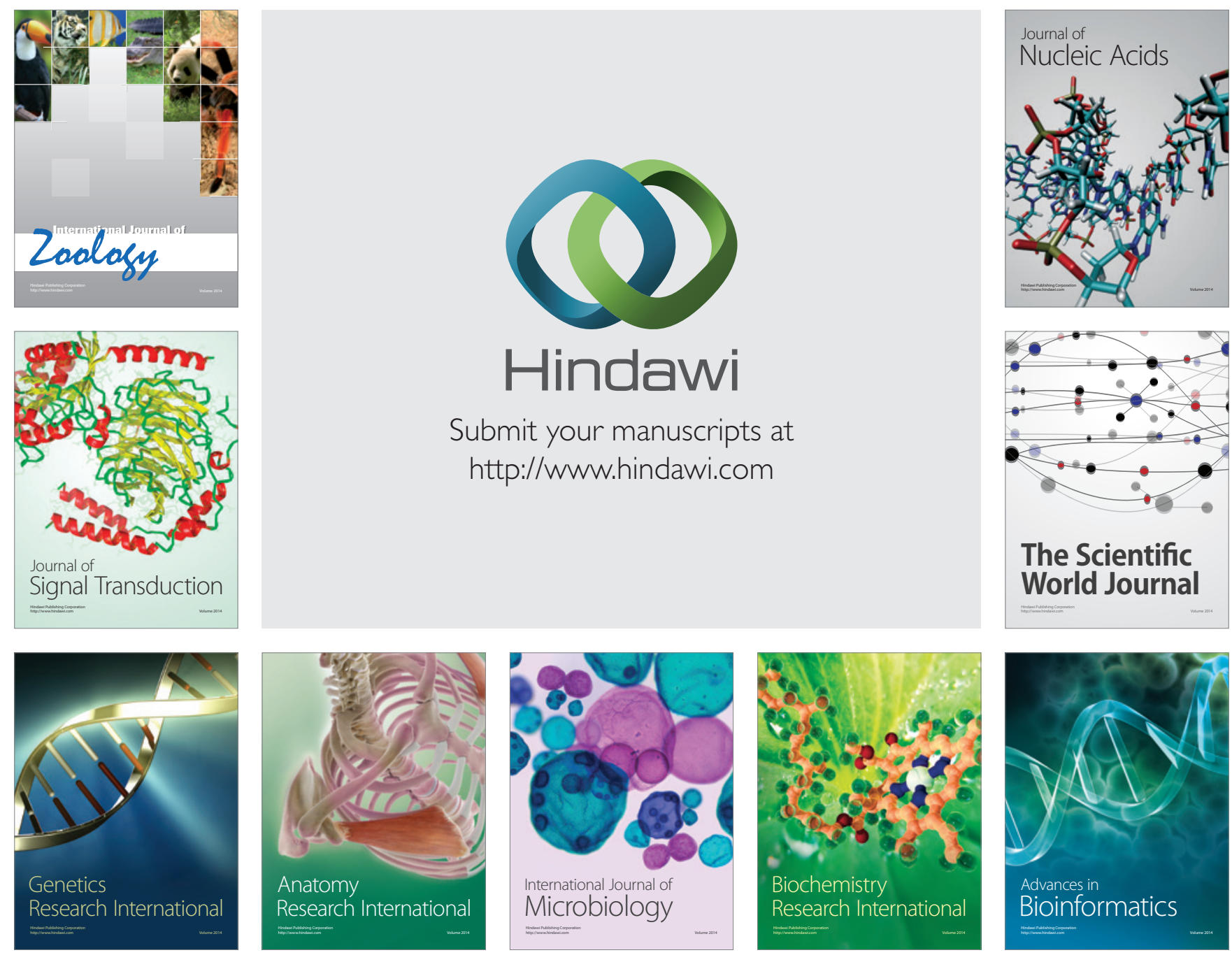

The Scientific World Journal
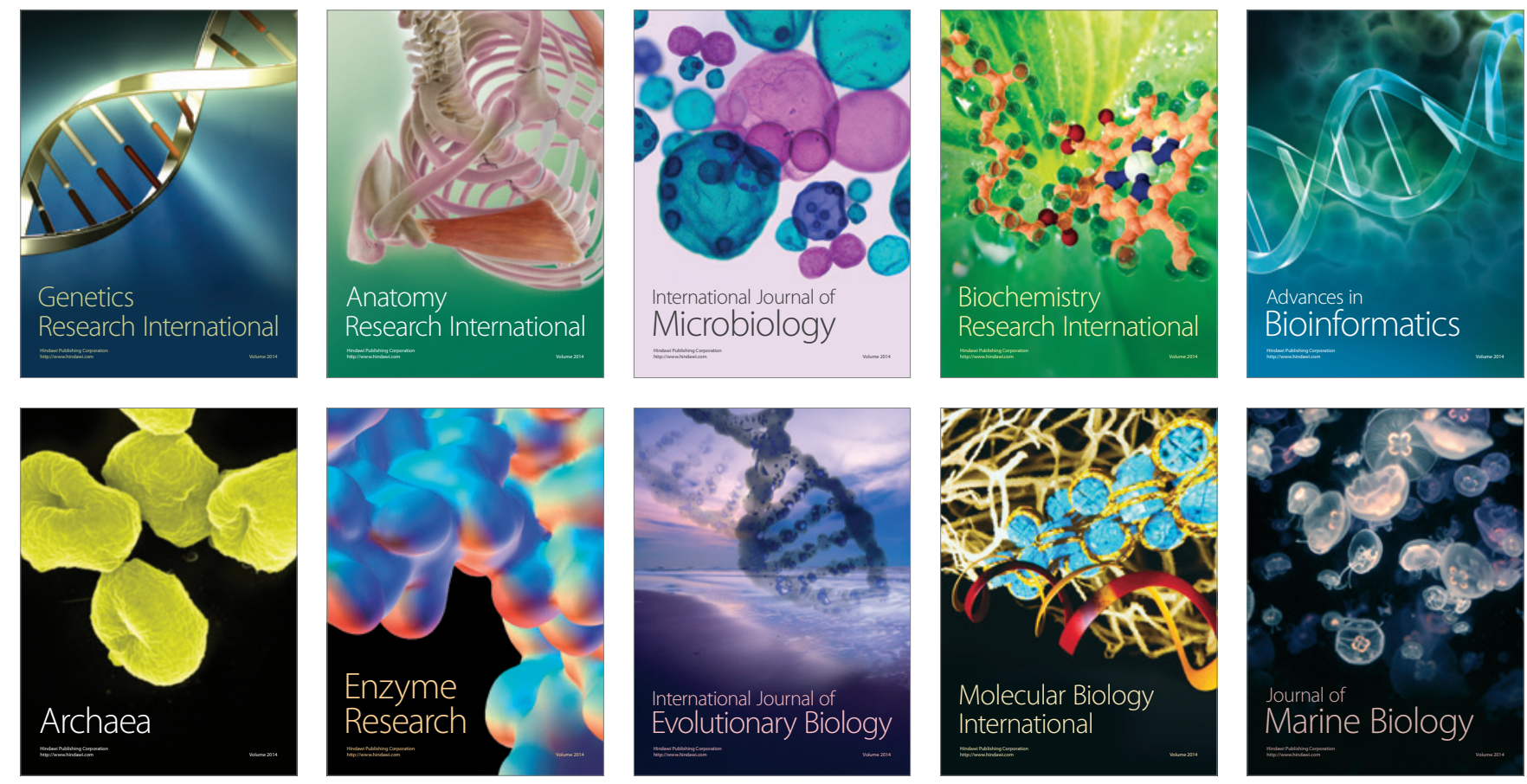